Int. J. Odontostomat., 11(1):113-117, 2017.

\title{
Study of the Relationships between Bur Diameter and Dental Implant Diameter
}

\author{
Estudio de las Relaciones entre Diámetro de Fresas y Diámetro de Implantes Dentales
}

\author{
Ricardo Cardozo1; Sergio Olate2,3; Pablo Navarro²; Javier Araya'; \\ Omar González'; Juan Carrasco' ${ }^{1} \&$ Claudia Zenteno ${ }^{1}$
}

CARDOZO, R.; OLATE, S.; NAVARRO, P.; ARAYA, J.; GONZALEZ, O.; CARRASCO, J. \& ZENTENO, C. Study of the relationships netween bur diameter and dental implant diameter. Int. J. Odontostomat., 11(1):113-117, 2017.

ABSTRACT: The bur used to construct the bed where a dental implant is installed is extremely important to treatment success. The aim of this investigation was to analyze the relationship between bur diameter and implant diameter in different areas. A descriptive study was designed to analyze 5 commercial brands currently on the market. The manufacturer's instructions were followed to establish the size and type of bur indicated for the study implants, which were regular, with a width between $3.5 \mathrm{~mm}$ and $4.0 \mathrm{~mm}$ and a length from $12 \mathrm{~mm}$ to $13 \mathrm{~mm}$. Drilling from the most apical region, the first measurement of width was established $3 \mathrm{~mm}$ cervically, the lower middle measurement $6 \mathrm{~mm}$ cervically, the upper middle measurement at $9 \mathrm{~mm}$ and the cervical measurement at $12 \mathrm{~mm}$. A scanning electron microscope was used standardized for all measurements; the data were analyzed using the Shapiro-Wilk test and the t-test, having considering a value of $p<0.05$ for significant differences. At apical level, all the implants were wider than the bur. The greatest differences between bur width and implant were observed at cervical level, maintaining a relation where the implant was always wider. In mediumsized areas, it was observed that in some systems the burs have a larger diameter than the study implants. A significant relation was established in the apical, upper middle and cervical areas. Bur morphology is related to implant morphology; no implant system is the same as another in terms of the implant-bur relation.

KEY WORDS: Dental implant, bur, primary stability

\section{INTRODUCTION}

Osseointegration has been defined as the intimate contact between bone tissue and implanted biomaterial, which involves the biological and mechanical considerations necessary for success (Ortega-Lopes et al., 2012). The value given to each variable depends on different surgical and prosthetic conditions as well as intersubject variations, demonstrating the variability and versatility needed for current implant systems.

The heightened stability and success of dental implants (De Moraes et al., 2015), over $90 \%$ in almost every case, reflects the progress made in all the processes involved. Albrektsson et al. (1998) suggested 6 key factors that determine the success of osseointegration: biocompatibility, implant design, surface type, state of the receptor bed, surgical technique and load conditions. The installation conditions of dental implants are essential among these criteria, such that drilling protocols must be constantly assessed. The drilling and resulting implant installation impact directly on the primary stability of the implant (Campos et al., 2012; Coelho et al., 2011) and thus the bone response that it is going to present; the bone quality of the receptor bed also influences this parameter (Olate et al., 2011).

When there are important differences between the prepared bone bed and the installed implant, this creates spaces that are quickly are filled with the blood

1 Unidad de Rehabilitación Oral, Facultad de Odontología, Universidad San Sebastián, Chile.

2 Division of Oral and Maxillofacial Surgery, Universidad de La Frontera, Temuco, Chile.

${ }^{3}$ Center for Biomedical Research, Universidad Autónoma de Chile, Chile. 
clot; there is no contact in these spaces between implant and bone and thus there is no contribution to the primary stability of the implant (Leonard et al., 2009; Coelho et al., 2010), leaving this up to other sectors of the prepared bed. It is possible that these spaces with no bone contact present a formation of woven bone that could contribute to secondary implant stability.

Interesting studies have analyzed implants inserted with an accurate fit in their respective implant beds, comparing them with implants inserted in beds without an accurate fit (over-drilled), in which the bed was larger than the implant. Their findings have shown that while bone resorption was occurring in the regions compressed by the implant, bone formation was occurring in the healing chamber at the same time (Campos et al.; Coelho et al.; Coelho et al., 2013; Bonfante et al., 2011). In this sense, the results observed in other studies focused on the contact between bone and implant through bone-to-implant contact (BIC) and bone area fraction occupied (BAFO) demonstrate the need to better recognize the relation between drilling and installed implant.

The aim of this study was to ascertain the relation between implant bur diameters and implants at different levels of each device.

\section{MATERIAL AND METHOD}

A comparative study was designed to examine the relationship between bur sizes and implant sizes in 5 commercial brands. For all the brands, a standard, regular internal connection implant was used, with diameters between $3.5 \mathrm{~mm}$ and $4 \mathrm{~mm}$ and lengths of up to $13 \mathrm{~mm}$ (Table I); each brand represented a different group.

Each implant was acquired in its original state for commercial sale. The packaging was removed and the implants were removed using the implant holder from each system. For each implant system 3 different units were analyzed, obtaining comparisons between the cervical, middle and apical areas, as well as between each unit assessed.

The measurements were taken through a LEO 1420VP scanning electron microscope (SEM) where different acceleration values and focal lengths were used according to the desired increase index of the image. Acceleration data were expressed in electron volts (Ev) and the focal length in millimeters ( $\mathrm{mm}$ ), obtaining images at different magnifications (50x, 500x, 1000x).

The manufacturer's instructions regarding the bur indicated for each implant were used for the comparison. This bur created a segmentation of implant and drill at the same levels, differentiating a cervical, middle and apical sector; the apical line was established $3 \mathrm{~mm}$ cervically from the lower edge of the implant and of the drill; the lower middle line was established 6 $\mathrm{mm}$ cervically from the same lower edge; the upper middle line was established at $9 \mathrm{~mm}$ and the cervical line was established at $12 \mathrm{~mm}$, measured from the lower edge of the implant. For the burs there was only one diameter measurement for each line described, whereas for the implants there were measurements at the level of the valleys and screws.

The measurements were taken by qualified personnel with experience in the use of this SEM system; each unit was measured individually, recording its values in a table designed specifically for the study. The data were analyzed with measures of central tendency and a statistical analysis with the ShapiroWilk test of normality and the t-test. The data were analyzed with the SPSS/PC + v. 20.0 software (SPSS, Chicago, USA), considering a value of $p<0.05$ for significant differences.

\section{RESULTS}

The study was conducted without complications. The measurements were taken cross-sectionally to the study implant in the selected sectors (Figs. 1 and 2).

Comparing all the analyzed groups, significant differences were determined on some levels. Table II hows differences observed in the measurements; note that at apical level, all the implants were wider than the bur used. At cervical level is where the greatest differences were observed between the bur width and the implant, maintaining a relation where the implant is always wider.

Statistically, the bur diameter was significantly different at apical level from the measurement $(p=$ $0.005)$, at upper middle level $(p=0.009)$ and at cervical level $(p=0.001)$, indicating that the burs are commonly smaller than the implants in those regions; there was no difference in the lower middle area $(p=$ 
CARDOZO, R.; OLATE, S.; NAVARRO, P.; ARAYA, J.; GONZALEZ, O.; CARRASCO, J. \& ZENTENO, C. Study of the relationships netween bur diameter and dental implant diameter. Int. J. Odontostomat., 11(1):113-117, 2017.

0.078), demonstrating that there is not always a relation between the diameters assessed in implant and bur (Table III).

Table I. Distribution of the 5 types of implants and commercial brands used

\begin{tabular}{lll}
\hline Brand name & Implant & Measurements \\
\hline Medigma & Fix tite & $3.75 \times 13$ \\
Biohorizons & Tapered internal & $3.8 \times 12$ \\
Alpha Bio & Atid & $3.75 \times 13$ \\
B \& W & Cónico ClH & $4.0 \times 13$ \\
Neodent & & $3.5 \times 13$ \\
\hline
\end{tabular}

Table II. Average diameters observed in 15 implants and final burs of 5 brands at apical, middle and upper levels

\begin{tabular}{ll}
\hline Analysis relationships & $\mathrm{p}$ \\
\hline Apical measurement & $0.005^{*}$ \\
Lower middle measurement & 0.078 \\
Upper middle measurement & $0.009^{*}$ \\
Cervical measurement & $0.001^{*}$ \\
\hline $\begin{array}{l}{ }^{*} \text { positive values indicate the implant is larger } \\
\text { than the bur; negative values indicate the bur } \\
\text { is larger than the implant. }\end{array}$
\end{tabular}

Table III. statistical relationships according to the measurements taken in the 15 implants and burs from the 5 brands.

\begin{tabular}{llllllllllll}
\hline \multicolumn{3}{c}{ Apical $(\mathrm{mm})$} & \multicolumn{3}{c}{ Lower middle $(\mathrm{mm})$} & \multicolumn{3}{c}{ Upper middle $(\mathrm{mm})$} & \multicolumn{2}{c}{ Cervical $(\mathrm{mm})$} \\
Implant & Bur & Difference & Implant & Bur & Difference & Implant & Bur & Difference & Implant & Bur & Difference \\
\hline 2.754 & 2.581 & 0.173 & 3.305 & 3.516 & -0.211 & 3.329 & 3.516 & -0.187 & 3.743 & 2.914 & 0.829 \\
2.717 & 2.218 & 0.499 & 3.023 & 2.446 & 0.577 & 3.049 & 2.426 & 0.623 & 3.364 & 2.462 & 0.902 \\
3.572 & 3.158 & 0.414 & 3.432 & 2.768 & 0.664 & 3.452 & 3.075 & 0.377 & 3.827 & 3.303 & 0.524 \\
3.123 & 3.179 & -0.056 & 3.490 & 3.6 & -0.110 & 3.461 & 3.48 & -0.019 & 3.636 & 3.615 & 0.021 \\
3.070 & 2.976 & 0.094 & 3.613 & 3.402 & 0.211 & 3.662 & 3.433 & 0.229 & 3.946 & 3.433 & 0.513 \\
\hline
\end{tabular}

* Significant differences $(p<0.05)$

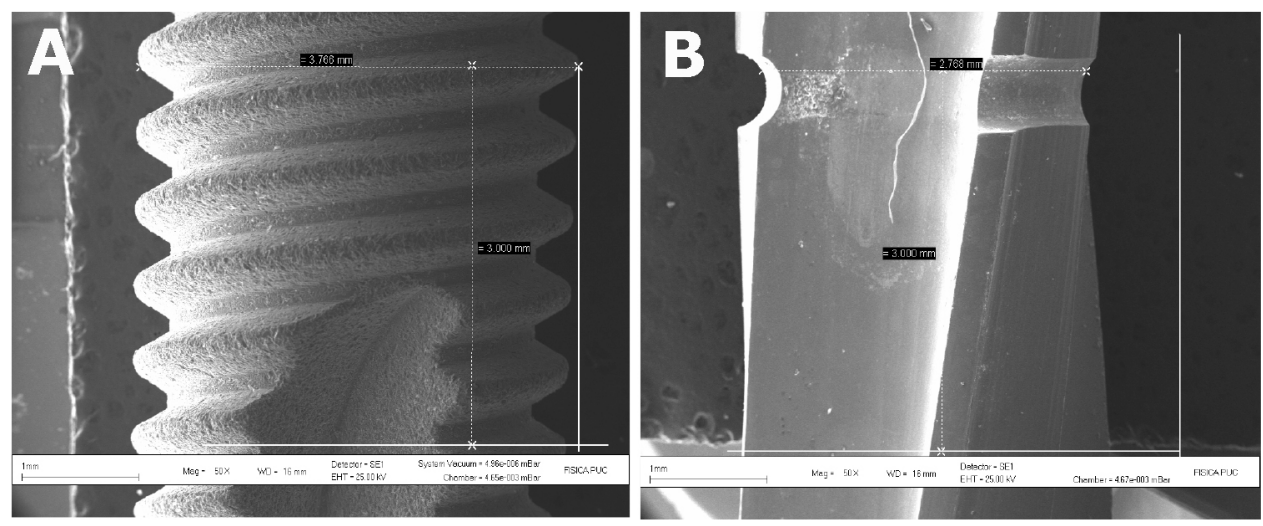

Fig. 1. Measurements taken through scanning electron microscope (SEM) LEO 1420VP: (a) diameter of the implant vs. (b) diameter of the bur in the middle section (Alpha Bio $\mathrm{Tec}^{\circledR}$ ).
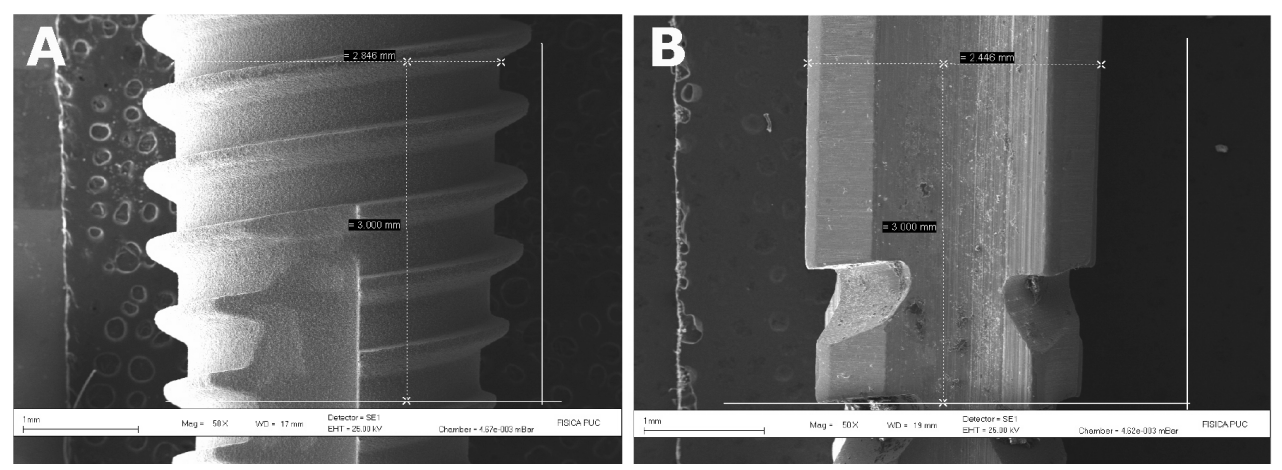

Fig. 2. Measurements taken through scanning electron microscope (SEM) LEO 1420VP: (a) diameter of the implant vs. (b) diameter of the bur in the middle section (Neodent ${ }^{\circledR}$ ). 


\section{DISCUSSION}

The evolution of modern implantology has made the long-term success of dental implants possible (de Moraes et al., 2015). Rates over $90 \%$ of survival show better results than other techniques in oralsurgery and can be related to the level of specialization for variables involved in the osseointegration process. Clinical studies and surgical experiences have shown that different types of implants with different designs can be osseointegratable, which demands the need for studies that can streamline the clinical results even further.

The relation between bur diameter and implant diameter is important to achieve primary stability (Olate et al., 2009); other factors such as bone quality, presence of cortical bone and surgical technique are also associated with primary stability; factors relative to the implant, such as morphology, length, diameter, surface structure and distance between screws are also related to this condition (Barewal et al., 2003).

In this sense, the highest rate of implant loss in type IV cortical bone with thin corticals and low trabecular density is frequently found in the upper maxilla, being caused, among other things, by insufficient primary stability (Hermann et al., 2005). The measurement of primary stability is complex every time clinicians evaluate it using percussion tests or their own perception during the insertion process, which is not the best method due to its limited objectivity (Bayarchimeg et al., 2013).

The initial results of this study show the variability in bur size and implant size among the different brands; the analyses of this study cannot establish the correct or incorrect condition among the different brands due to the limitation of sample units; however, such discrepancies do address the low level of standardization existing among different manufacturing systems.

Surgical modifications such as sub-drilling or the bur diameter in relation to the implant diameter can also affect it (Bilhan et al., 2010). Although sub-drilling can certainly have a positive effect on primary stability in trabecular bones, it must be noted that in uncontrolled conditions it can cause stress on the bone, which although beneficial in the sense of gaining a better primary stability can result in necrosis and local bone ischemia in the bone-implant interface, affecting osseointegration (Nedir et al., 2004). This concept takes on even greater relevance given that secondary stability is also determined by the tissue response to the surgical trauma and the implant surface.

This variability limits the surgeon's action in the installation phase because adjusting the system to the bone bed and to the bone quality has poor predictability when the real relation between the bur and the implant is not ascertained.

Reports published on the relation between the primary stability of the implant and its shape (conical or cylindrical) is controversial. Ostman et al. (2006) reported that conical implants have lower rates of implant stability quotient (ISQ) than cylindrical ones; similar results were found by Bilham et al. (2010). Rokn et al. (2009) found the opposite results to those of Ostman et al. and Bilham et al., where the conical ones were more stable; this may be due to the deficient relation between bur and implant. Olate et al. indicated that conical implants presented better bone repair conditions than cylindrical implants, where the bur morphology was a variable that influenced bone repair.

In this case, the macrogeometry of the bur in relation to its respective implant is made relevant in that parallelisms are similar and that the conicity or parallelism of the surgical bur is specific to conical or cylindrical implants.

Another analysis observed a variable relation among different areas of the implant and the bur, which creates another difficulty in the presence of spaces with no bone contact and the likely reduction in BIC. In this study, the lower middle area presented no relation to the bur diameter so that the morphological definition of the implant bed in this zone is complex; a likely cause for this lies in the variability of the implant design without presenting similar variabilities in the manufacture of the bur.

Finally, it can be concluded that bur morphology is related to implant morphology; no implant system is the same as another in terms of the relation between implant and bur. The processes must be standardized and specific information provided to the clinician for decision-making in the intraoperative stage. 
CARDOZO, R.; OLATE, S.; NAVARRO, P.; ARAYA, J.; GONZALEZ, O.; CARRASCO, J.; ZENTENO, C. Estudio de las Relaciones entre Diámetro de Fresas y Diámetro de Implantes Dentales. Int. J. Odontostomatol. 1(1):113-117, 2017.

RESUMEN: La relación entre la fresa utilizada para construir el lecho donde se instala el implante dental tiene alta importancia en el éxito del tratamiento. El objetivo de esta investigación fue analizar la relación entre el diámetro de fresa y el diámetro de implantes en diferentes áreas. Se diseñó un estudio descriptivo analizando utilizando 5 marcas comerciales vigentes en el mercado; se siguió las instrucciones del fabricante para establecer el tamaño y tipo de fresa indicada para el implante en análisis, los cuales fueron de tipo regular considerando medidas en ancho de entre $3,5 \mathrm{~mm}$ y $4,0 \mathrm{~mm}$ y en largo de 12 $\mathrm{mm}$ a $13 \mathrm{~mm}$. Desde la región mas apical de implantes y fresar se estableció $3 \mathrm{~mm}$ hacia cervical la primera medición de ancho, $6 \mathrm{~mm}$ hacia cervical la medición media inferior, a $9 \mathrm{~mm}$ la medición media superior y a $12 \mathrm{~mm}$ la medición cervical; para esta medición se utilizó microscopio electrónico de barrido estandarizado para todas las mediciones; los datos fueron analizados con pruebas estadísticas de Shapiro-Wilk y la prueba t-test, considerando un valor de $p<0,05$ para considerar diferencias significativas. A nivel apical, todos los implantes fueron mas anchos que las fresas utilizadas. A nivel cervical es donde se observan las mayores diferencias entre el ancho de la fresa y del implante manteniendo una relación donde el implante siempre es mas ancho. En áreas medianas, se observó que en algunos sistemas las fresas son de mayor diametro a los implantes analizados. Se estableció relación significativa en las regiones apical, media superior y cervical. La morfología de fresas presenta relación con la morfología implantaría; ningún sistema de implantes es igual a otro en términos de relación implante y fresa.

PALABRA CLAVE: implante dental, fresa, estabilidad primaria

\section{REFERENCES}

Albrektsson, T.; Branemark, P.I.; Hansson, H. A. Biological factor contributing to failures of osseointegrated oral implants. Eur. J. Oral Sci., 106 (3):721-64, 1998.

Bayarchimeg, D.; Namgoong, H.; Kim, B.K.; Kim, M.D.; Kim, S.; Kim, T.I.; Seol, Y.J.; Lee, Y.M.; Ku, Y.; Rhyu, I.C.; Lee, E.H.; Koo, K.T. Evaluation of the correlation between insertion torque and primary stability of dental implants using a block bone test. J. Periodontal Implant. Sci., 43(1):30-6, 2013.

Barewal, R.M.; Oates, T.W.; Meredith, N.; Cochran, D.L. Resonance frequency measurement of implant stability in vivo on implants with a sandblasted and acid-etched surface. Int. J. Oral Maxillofac. Implants, 18:641-51, 2003.

Bilhan, H.; Geckili, O.; Mumcu, E.; Bozdag, E.; Sünbüloglu, E.; Kutay, $O$. Influence of surgical technique, implant shape and diameter on the primary stability in cancellous bone. J. Oral Rehabil., 37: 900-7, 2010.

Bonfante, E.A.; Granato, R.; Marin, C.; Susuki, M.; Oliveira, S.R.; Giro, G.; Coelho, P.G. Early bone healing and biomechanical fixation of dual acid etched and as-machined implants with healing chambers: An experimental study in dogs. Int. J. Oral Maxillofac. Implants, 26:75-82, 2011.
Campos, F.E.; Gomes, J.B.; Marin, C.; Teixeira, H.S.; Suzuki, M.; Witek, L.; Zanetta-Barbosa, D.; Coelho, P.G. Effect of drilling dimensión on implant placement torque and early osseointegration stages : an experimental study in dogs. J. Oral Maxillofac. Surg., 70:e43-50, 2012.

Coelho, P.G.; Granato, R.; Marin, C.; Bonfante, E.A.; Janal, M.N.; Susuki, M. Biomechanical and bone histomorphologic evaluation of four surfaces on plateau root form implants: an experimental study in dogs. Oral Surg. Oral Med. Oral Pathol. Oral Radiol. Endod., 109:e39-45, 2010.

Coelho, P.G.; Granato, R.; Marin, C.; Teixeira, H.S.; Susuki, M.; Valverde, G.B.; Janal, M.N.; Lilin, T.; Bonfante, E.A. The effect of different implant macrogeometries and surface treatment in early biomechanical fixation: an experimental study in dogs. J. Mech. Behav. Biomed. Mater., 4:1974-81, 2011.

Coelho, P.G.; Marin, C.; Teixeira, H.S.; Campos, F.E.; Gomes, J.B.; Guastaldi, F.; Anchieta, R.B.; Silveira, L.; Bonfante, E.A. Biomechanical evaluation of undersized drilling on implant biomechanical stability at early implantation times. J. Oral Maxillofac. Surg., 71:e69-75, 2013.

De Moraes, P.H.; Olate, S.; Lauria, A.; Asprino, L.; de Moraes, M.; Albergaria-Barbosa, J.R. 8-10 year follow-up survival of dental implants in maxillae with or without autogenous bone graft reconstruction. Int. J. Clin. Exp. Med., 8:19282-9, 2015.

Herrmann, I.; Lekholm, U.; Holm, S.; Kultje, C. Evaluation of patient and implant characteristics as potential prognostic factors for oral implant failures. Int. J. Oral Maxillofac. Implants, 20: 220-30, 2005.

Leonard, G.; Coelho, P.; Polyzois, I.; Stassen, L.; Claffey, N. A study of the bone healing kinetics of plateau versus screw root design titanium dental implants. Clin. Oral Implants Res., 20:232-9, 2009.

Nedir, R.; Bischof, M.; Szmukler-Moncler, S.; Bernard, J.P.; Samson, J. Predicting osseointegration by means of implant primary stability. Clin. Oral Implants Res., 15:520-8, 2004.

Ostman, P.O.; Hellman, M.; Wendelhag, I.; Sennerby, L. Resonance frequency analysis measurements of implants at placement surgery. Int. J. Prosthodont., 19:77-83, 2006.

Ortega-Lopes, R.; Olate, S.; Noia, C.F.; Chaves Netto, H.D.M.; de Moraes, M.; Mazzonetto, R. Influence of diameter and length of implant on late dental implant failure. Int. J. Odontostomatol., 6: 77-80, 2012.

Olate, S.; Chaves Netto, H.D.M.; Muñante-Cárdenas, J.L.; Mazzonetto, R.; Albergaria-Barbosa, J.R. The cervical área of dental implants present more osseous formation tan apical área in different load and design condition. Prelimiary results. Int. J. Morphol., 27:407-12, 2009.

Olate, S.; Chaves Netto, H.D.M.; Klüppel, L.; Mazzonetto, R.; Albergaria-Barbosa, J.R. Mineralized tissue formation associated with 2 different dental implant designs: Histomorphometric analyses perfermed in dogs. J. Oral Implantol., 37: 319-24, 2011.

Rokn, A.R.; Ghahroudi, A.A.R.; Mesgarzadeh, A.; Miremadi, S.A.; Fard, M.J.K. Evaluating stability changes of tapered roughened surface implants in different bone types and fast loading: A prospective clinical cohort study. J. Periodontol. Implant Dent., 1: 36-42, 2009.

\section{Correspondencia:}

Prof. Dr. Sergio Olate

Universidad de La Frontera

Temuco

CHILE

Received: $10-10-2016$

Accepted: 21-12-2016

Email: sergio.olate@ufrontera.cl 